\title{
Impact of antibiotic treatment on immune-checkpoint blockade efficacy in advanced non-squamous non-small cell lung cancer
}

\author{
Florian Huemer ${ }^{1, *}$, Gabriel Rinnerthaler ${ }^{1, *}$, Theresa Westphal ${ }^{1}$, Hubert HackI ${ }^{4}$, \\ Georg Hutarew ${ }^{5}$, Simon Peter Gampenrieder ${ }^{1}$, Lukas Weiss ${ }^{1}$ and Richard \\ Greil1,2,3 \\ ${ }^{1}$ IIIrd Medical Department, Paracelsus Medical University Salzburg, Salzburg, Austria \\ ${ }^{2}$ Salzburg Cancer Research Institute (SCRI), Salzburg, Austria \\ ${ }^{3}$ Cancer Cluster Salzburg (CCS), Salzburg, Austria \\ ${ }^{4}$ Division of Bioinformatics, Biocenter, Medical University of Innsbruck, Innsbruck, Austria \\ ${ }^{5}$ Institute of Pathology, Paracelsus Medical University Salzburg, Salzburg, Austria \\ *These authors have contributed equally to this work \\ Correspondence to: Richard Greil, email: r.greil@salk.at \\ Keywords: immune-checkpoint blockade; antibiotics; non-squamous non-small cell lung cancer; progression-free survival; overall \\ survival \\ Received: October 19, $2017 \quad$ Accepted: March 05, $2018 \quad$ Published: March 27, 2018 \\ Copyright: Huemer et al. This is an open-access article distributed under the terms of the Creative Commons Attribution License \\ 3.0 (CC BY 3.0), which permits unrestricted use, distribution, and reproduction in any medium, provided the original author and \\ source are credited.
}

\section{ABSTRACT}

Introduction: Despite durable responses from immune-checkpoint blockade (ICB) in a subset of patients with advanced non-small cell lung cancer (NSCLC), the majority of patients do not derive benefit from this treatment. In this analysis we evaluated the impact of concomitant administration of antibiotics during initiation of ICB on clinical outcome.

Methods: Advanced non-squamous NSCLC patients receiving ICB as second- or later line between 2015 and 2017 at our tertiary cancer center in Salzburg (Austria) were included. Concomitant use of antibiotics was defined as administration of antibiotics within a time frame of one month before or one month after initiation of ICB (AB+-group).

Results: Of the 30 patients included, 11 (36.7\%) received antibiotics one month before or one month after start of ICB ( $\mathrm{AB}^{+}$-group). Median PFS on ICB was in favor of the $A B^{-}$-group (AB: 3.1 months [95\%CI: 3.0-16.3]; $\mathrm{AB}^{+}: 2.9$ months, [95\%CI: 1.9-NA]; HR=0.46 [95\%CI: 0.12-0.90], $\mathrm{p}=0.031$ ). Furthermore, median OS was significantly longer in the $A B-$-group (AB: 15.1 months [95\%CI: 11.1$\mathrm{NA}$ ]; $\mathrm{AB}^{+}: \mathbf{7 . 5}$ months [95\%CI: 6.3-NA]; $\mathrm{HR}=0.31$ [95\%CI: 0.02-0.78], $\mathrm{p}=0.026$ ). In a multivariate analysis, the antibiotic treatment status was identified as the only parameter statistically significantly associated with PFS $(p=0.028)$ and OS $(p=0.026)$.

Conclusions: Stratification of patients according to the antibiotic treatment status is warranted in future trials investigating ICB.

\section{INTRODUCTION}

With over 155,000 and 183,000 estimated deaths, lung cancer will be the leading cause of cancer-related mortality in the United States [1] and in Europe [2] in 2017 , respectively. In recent years, strategies unleashing pre-existing anti-tumor responses by immune-checkpoint blockade (ICB) have revolutionized cancer therapy and 
have led to the approval of several immune-checkpoint inhibitors for second-line therapy in advanced non-small cell lung cancer (NSCLC) [3-6]. While programmed death-ligand 1 (PD-L1) expression on tumor cells was predictive of achieving benefit from ICB during secondline treatment of metastatic non-squamous NSCLC, such an association could not been shown in squamous NSCLC [3-5]. Preclinical studies assume an influence of the composition of the gut microbiota on the benefit from ICB by improving dendritic cell function and T-cell activation $[7,8]$.

In our retrospective monocentric analysis, we tested the influence of antibiotic treatment in temporal proximity to the initiation of ICB on clinical outcome in previously treated advanced non-squamous NSCLC.

\section{RESULTS}

Between May 2015 and November 2017, fortyfour patients with advanced non-squamous NSCLC were treated with ICB as second- or later line treatment at our institution and 36 of them were evaluable for treatment outcome based on our inclusion criteria. Overall 6 patients had to be excluded due to ICB treatment within clinical trials with unpublished primary outcomes. Therefore, 30 patients (25 patients treated with nivolumab and 5 patients treated with pembrolizumab) were included in this retrospective analysis.

Baseline characteristics are depicted in Table 1. Eleven patients received antibiotics during start of ICB ( $\mathrm{AB}^{+}$-group) while the remaining 19 patients did not (AB-group). Application of antibiotics was initiated due to upper respiratory tract infection, fever without a focus or as preoperative antibiotic prophylaxis in $45.5 \%, 45.5 \%$ and $9 \%$ of patients. Penicillins ( 7 of 11 , $64 \%$ ), fluoroquinolones ( 4 of $11,36 \%$ ) and carbapenems ( 2 of $11,18 \%$ ) were the most frequently administered antibiotics. The majority of patients were treated with ICB in second-line ( $\mathrm{AB}^{-} 63.2 \%$ versus $\mathrm{AB}^{+} 45.5 \%$, $\mathrm{p}=0.773)$. After ICB, subsequent therapy was initiated in 17 patients $(58 \%)$. The PD-L1 expression status was available in $90 \%$ of patients.

Median progression-free survival (PFS) on ICB was statistically significantly in favor of the $\mathrm{AB}^{-}$-group $(\mathrm{AB}$ : 3.1 months [95\%CI: 3.0-16.3]; $\mathrm{AB}^{+}: 2.9$ months [95\%CI: 1.9-NA]; $\mathrm{HR}=0.46$ [95\%CI: $0.12-0.90], \mathrm{p}=0.031$ ) with a corresponding 4-month PFS rate of $36.8 \%$ versus $9.1 \%$, respectively $(\mathrm{HR}=0.41$ [95\%CI: $0.11-0.86], \mathrm{p}=0.024)$ as outlined in Figure 1A.

This PFS benefit translated into a superior median overall survival (OS) in the $\mathrm{AB}^{-}$-group $\left(\mathrm{AB}^{-}: 15.1\right.$ months [95\%CI: 11.1-NA]; $\mathrm{AB}^{+}: 7.5$ months [95\%CI: 6.3-NA]; $\mathrm{HR}=0.31$ [95\%CI: 0.02-0.78] $\mathrm{p}=0.026$; Figure 1B). No patient in the $\mathrm{AB}^{+}$-group died due to the infection that had necessitated concomitant antibiotic administration with the initiation of ICB.
The PD-L1 status was neither predictive in terms of PFS (PD-L1 ${ }^{+}: 3.1$ months [95\%CI: 2.8-NA]; PD-L1: 3.0 months [95\%CI: 2.9-NA]; HR 0.74 [95\%CI: $0.31-$ $1.65], \mathrm{p}=0.424$; Figure $2 \mathrm{~A}$ ), nor in terms of OS (PD-L1 ${ }^{+}$: 11.2 months [95\%CI: 9.4-NA]; PD-L1: 13.6 months [95\%CI: 8.9-NA]; HR 0.93 [95\%CI: 0.30-2.88], $\mathrm{p}=0.897$; Figure 2B) in the entire non-squamous NSCLC cohort. No difference in PFS was observed between the $\mathrm{AB}^{-}$and $\mathrm{AB}^{+}$-group during therapy prior to $\mathrm{ICB}\left(\mathrm{AB}^{-}: 6.3\right.$ months [95\% $\mathrm{CI}: 5.6-11.0]$; $\mathrm{AB}^{+}: 6.5$ months [95\% $\mathrm{CI}: 5.3-\mathrm{NA}$; $\mathrm{HR}=1.23$ [95\%CI: 0.52-3.04], $\mathrm{p}=0.614$; Figure $3 \mathrm{~A}$ ) or during subsequent therapy $\left(\mathrm{AB}^{-}: 3.1\right.$ months $[95 \% \mathrm{CI}$ : 2.1-NA]; $\mathrm{AB}^{+}: 2.4$ months [95\%CI: $\left.1.5-\mathrm{NA}\right] ; \mathrm{HR}=1.45$ [95\%CI: 0.47-5.20], $\mathrm{p}=0.470$; Figure $3 \mathrm{~B}$ ). In a multivariate analysis including the parameters antibiotic treatment status, sex, immune-checkpoint inhibitor, EGFR mutation status, ALK translocation status, number of prior therapy lines, PD-L1 expression status, and immune-related adverse events, the antibiotic treatment status was the only parameter statistically significantly associated with PFS $(\mathrm{HR}=5.34, \mathrm{p}=0.028)$ and $\mathrm{OS}(\mathrm{HR}=14.81, \mathrm{p}=0.026)$ in our non-squamous NSCLC cohort receiving ICB (Table 2).

During treatment with immune-checkpoint inhibitors immune-related adverse events occurred in $57.9 \%$ and $27.3 \%$ in $\mathrm{AB}^{-}$and $\mathrm{AB}^{+}$patients, respectively. Only grade $\leq 2$ adverse events were documented whereas three patients $(15.8 \%)$ in the $\mathrm{AB}^{-}$group necessitated systemic cortisone administration resulting in a temporary ICB pause in two of these patients. One patient had to discontinue ICB due to a prolonged therapy-induced pneumonitis (Table 3 ).

\section{DISCUSSION}

According to a large epidemiologic study comparing 125,441 cases and 490,510 controls recurrent antibiotic exposure and associated bacterial dysbiosis promotes cancer formation in various organs [9]. The risk of developing lung cancer was increased by 1.4-fold when more than 5 courses of penicillin were administered. Animal studies suggest that the relative abundance of certain bacterial species such as Bifidobacterium is crucial for dendritic cell maturation, enhanced cytotoxic T-lymphocyte (CTL) priming, accumulation of CTL in the tumor microenvironment and finally for the efficacy of ICB [8]. Due to immunosuppressive effects of the underlying malignancy itself and chemotherapy induced temporary leukopenia, cancer patients are prone to bacterial infections and often necessitate antibiotic treatment [10]. Our analysis of an unselected, consecutive advanced non-squamous NSCLC cohort demonstrated a statistically significant and clinically meaningful PFS (HR $0.46 ; p=0.031)$ and $\mathrm{OS}(\operatorname{HR} 0.31 ; \mathrm{p}=0.026)$ advantage for the $\mathrm{AB}^{-}$-group during initiation of ICB when compared to the $\mathrm{AB}^{+}$-group. In order to rule out differences in biologic aggressiveness between the $\mathrm{AB}^{-}$and $\mathrm{AB}^{+}$-group, PFS during prior therapy $(\mathrm{HR} 1.23$; $\mathrm{p}=0.614)$ and during subsequent 
Table 1: Baseline characteristics of patients with advanced non-squamous NSCLC treated with immune-checkpoint blockade (ICB; $\mathbf{n}=\mathbf{3 0})$

\begin{tabular}{|c|c|c|c|c|}
\hline & & $\begin{array}{l}\mathbf{A B}^{+} \text {-group } \\
\quad \mathbf{N}(\%)\end{array}$ & $\mathbf{A B}^{-} \operatorname{group}^{\mathrm{b}} \mathbf{N}(\%)$ & p-value \\
\hline Overall & & $11(36.7)^{\mathrm{c}}$ & $19(63.3)$ & \\
\hline \multirow[t]{2}{*}{ Sex } & male & $7(63.6)$ & $7(36.8)$ & \multirow{2}{*}{0.257} \\
\hline & female & $4(36.4)$ & $12(63.2)$ & \\
\hline \multirow[t]{2}{*}{ Anti-PD1 antibody } & nivolumab & $8(72.7)$ & $17(89.5)$ & \multirow{2}{*}{0.327} \\
\hline & pembrolizumab & $3(27.3)$ & $2(10.5)$ & \\
\hline \multirow[t]{3}{*}{$\begin{array}{l}\text { Activating EGFR } \\
\text { mutation }^{\text {d }}\end{array}$} & yes & $4(36.4)$ & $2(10.5)$ & \multirow{3}{*}{0.156} \\
\hline & no & $7(63.6)$ & $16(84.2)$ & \\
\hline & missing & $0(0.0)$ & $1(5.3)$ & \\
\hline \multirow[t]{3}{*}{ ALK translocation ${ }^{\mathrm{d}}$} & yes & $1(9.1)$ & $1(5.3)$ & \multirow{3}{*}{0.476} \\
\hline & no & $8(72.7)$ & $17(89.4)$ & \\
\hline & missing & $2(18.2)$ & $1(5.3)$ & \\
\hline \multirow[t]{5}{*}{ Prior therapy lines } & 1 & $5(45.5)$ & $12(63.2)$ & \multirow{5}{*}{0.773} \\
\hline & 2 & $2(18.2)$ & $4(21.1)$ & \\
\hline & 3 & $1(9.1)$ & $2(10.5)$ & \\
\hline & 4 & $0(0.0)$ & $1(5.3)$ & \\
\hline & 5 & $1(9.1)$ & $0(0.0)$ & \\
\hline \multirow[t]{4}{*}{ Prior therapy $^{\mathrm{e}}$} & platinum-based + pemetrexed & $3(27.3)$ & $10(52.6)$ & \multirow{4}{*}{0.048} \\
\hline & $\begin{array}{c}\text { platinum-based }+ \text { docetaxel or } \\
\text { gemcitabine }\end{array}$ & $2(18.2)$ & $5(26.3)$ & \\
\hline & TKI & $5(45.5)$ & $1(5.3)$ & \\
\hline & other monochemotherapy & $0(0.0)$ & $3(15.8)$ & \\
\hline \multirow[t]{4}{*}{ Subsequent therapy } & docetaxel & $2(18.2)$ & $4(21.1)$ & \multirow{4}{*}{0.380} \\
\hline & TKI & $1(9.1)$ & $3(15.7)$ & \\
\hline & other chemotherapy/trial & $1(9.1)$ & $6(31.6)$ & \\
\hline & no subsequent therapy & $7(63.6)$ & $6(31.6)$ & \\
\hline \multirow[t]{3}{*}{$\begin{array}{l}\text { Indication for } \mathrm{AB} \\
\text { application }\end{array}$} & upper respiratory tract infection & $5(45.5)$ & & \\
\hline & fever without a focus & $5(45.5)$ & & \\
\hline & $\begin{array}{l}\text { Preoperative antibiotic } \\
\text { prophylaxis }\end{array}$ & $1(9.0)$ & & \\
\hline \multirow[t]{3}{*}{ PD-L1 status ${ }^{\mathrm{f}}$} & Positive & $5(45.5)$ & $10(52.6)$ & \multirow{3}{*}{0.733} \\
\hline & Negative & $4(36.4)$ & $8(42.1)$ & \\
\hline & Missing & $2(18.1)$ & $1(5.3)$ & \\
\hline
\end{tabular}

(Continued) 


\begin{tabular}{lcccc}
\hline & & $\mathbf{A B}^{+}-$group $^{\mathbf{a}}$ & $\mathbf{A B}^{-}$group $^{\mathbf{b}} \mathbf{N}(\%)$ & p-value \\
\hline PD-L1 status (categorical) & $<1 \%$ & $4(36.4)$ & $8(42.1)$ & \\
& $1-50 \%$ & $1(9.1)$ & $5(26.3)$ & 0.479 \\
& $>50 \%$ & $4(36.4)$ & $5(26.3)$ & $1(5.3)$ \\
\hline
\end{tabular}

${ }^{\mathrm{a}} \mathrm{AB}^{+}$-group: patient group that received antibiotics within a time frame of one month before or one month after initiation of immune-checkpoint blockade.

${ }^{\mathrm{b}} \mathrm{AB}$-group: antibiotic-naïve patients within a time frame of one month before or one month after initiation of immunecheckpoint blockade.

'In one patient transformation of EGFR mutant NSCLC into small-cell lung cancer was histologically proven during subsequent therapy to ICB.

${ }^{d}$ EGFR mutation status and ALK translocation status were routinely assessed. Some patients had missing data on molecular alterations due to consumed tumor material.

ePrior therapy in one patient in the $\mathrm{AB}^{+}$-group is unknown.

fPD-L1 expression status on tumor cells was assessed by immunohistochemistry utilizing the anti-PD-L1 clone 22C3 from Dako $^{\circledR}$. In three patients PD-L1 status could not be assessed due to consumed tumor material.

TKI: tyrosine kinase inhibitor; AB: antibiotics; PD-L1: programmed death-ligand 1; EGFR: epidermal growth factor receptor; ALK: anaplastic lymphoma kinase.

therapy $(\mathrm{HR}=1.45 ; \mathrm{p}=0.470)$ were compared without detecting a statistically significant difference between the groups (Figure 3). It is noteworthy, that more patients in the $\mathrm{AB}$-group $(68 \%)$ received subsequent therapy after ICB in comparison to the $\mathrm{AB}^{+}$-group (36\%), which might have affected OS results. Non-squamous NSCLC patients harboring an activating mutation of the epidermal growth factor receptor (EGFR) gene might derive less benefit from

A

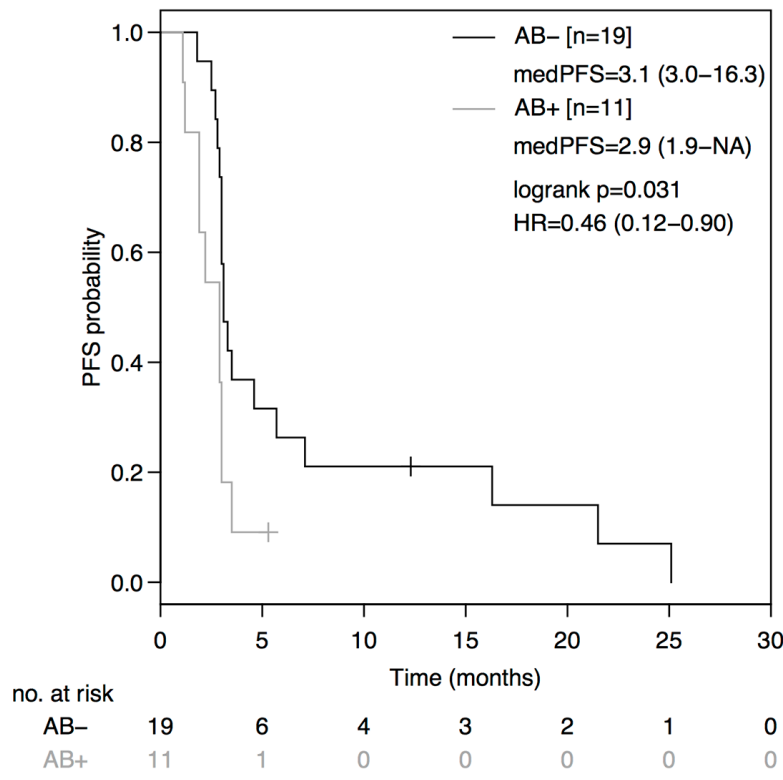

ICB as previously reported $[4,11]$. However, according to the multivariate analysis only the antibiotic treatment status had a statistically significant impact on PFS and OS, while this was not the case for several other parameters such as EGFR mutation or PD-L1 expression status (Table 2).

Clinical data on the influence of antibiotics on ICB efficacy are sparse. Routy et al. have recently reported on the influence of antibiotic use on ICB efficacy including

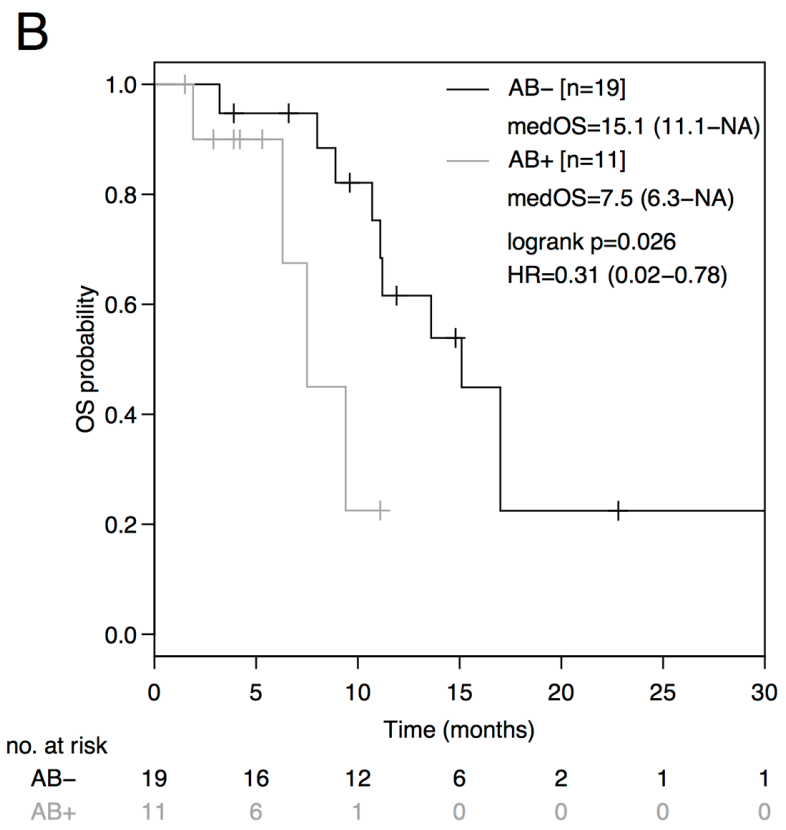

Figure 1: PFS and OS from initiation of immune-checkpoint blockade (ICB) based on antibiotic treatment status. Comparison of Kaplan-Meier curves for PFS (A) and OS (B) between $\mathrm{AB}^{-}$and $\mathrm{AB}^{+}$advanced non-squamous NSCLC groups. HR is hazard ratio, $95 \%$ confidence interval in brackets. 
various types of cancer [12]. In a subset analysis, they described a PFS and OS disadvantage for the NSCLC cohort receiving antibiotics two months before or within one month after ICB initiation (median PFS: $\mathrm{AB}^{+}: 3.5$ months versus $\mathrm{AB}^{-} 4.1$ months, $\mathrm{p}=0.017$; median $\mathrm{OS}$ : $\mathrm{AB}^{+} 11.5$ months versus $\mathrm{AB}^{-} 20.6$ months, $\mathrm{p}<0.001$ ) [12]. Furthermore, a relative abundance of Akkermansia muciniphila in the stool of patients was associated with
A

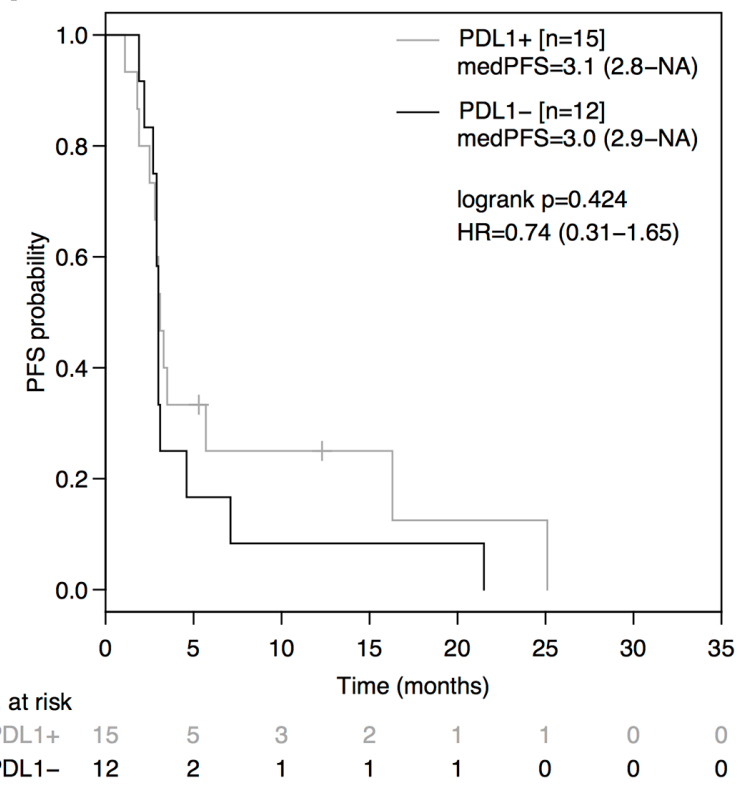

B

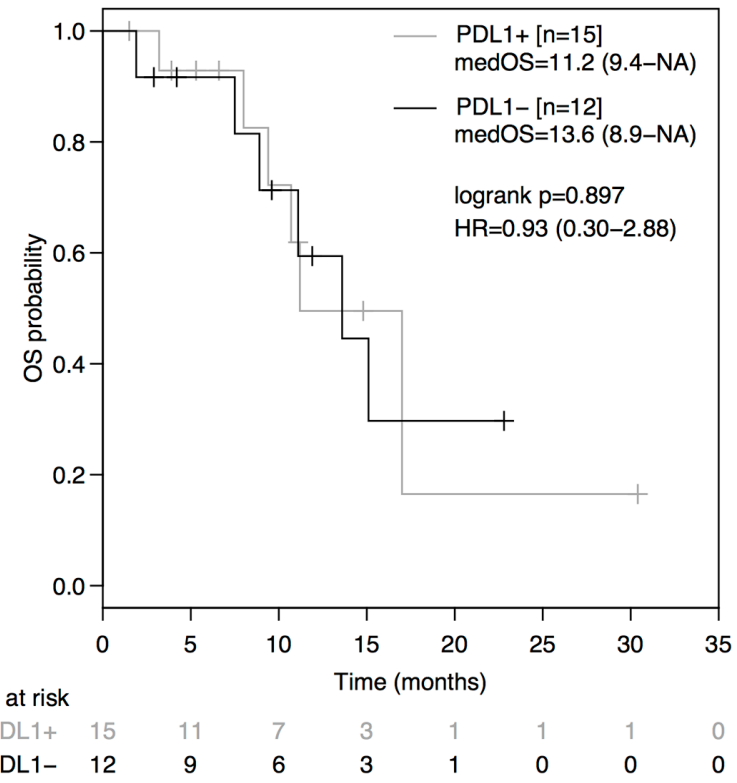

Figure 2: PFS and OS from initiation of immune-checkpoint blockade (ICB) based on the PD-L1 expression status. Comparison of Kaplan-Meier curves for PFS (A) and OS (B) between PD-L1 negative and PD-L1 positive advanced non-squamous NSCLC groups. HR is hazard ratio, $95 \%$ confidence interval in brackets.

A

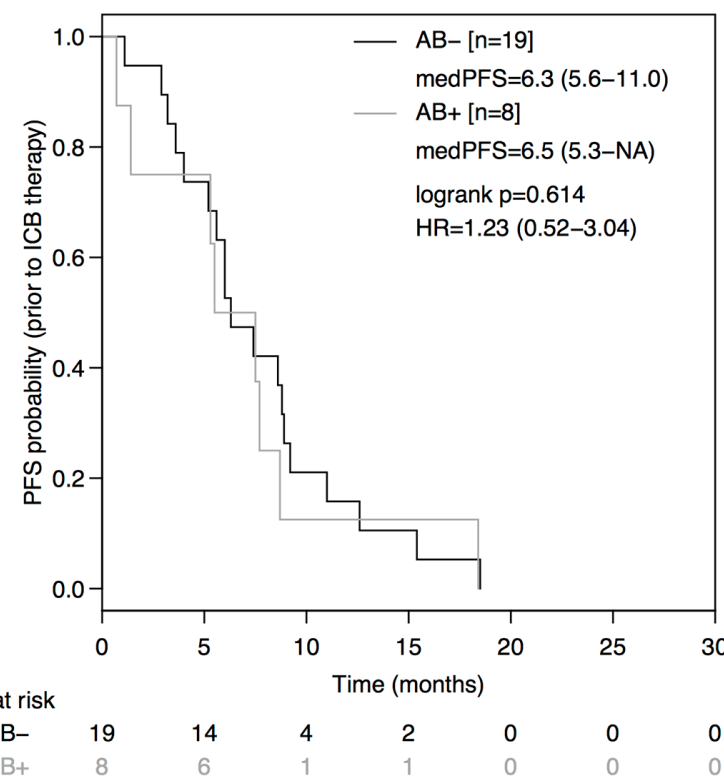

B

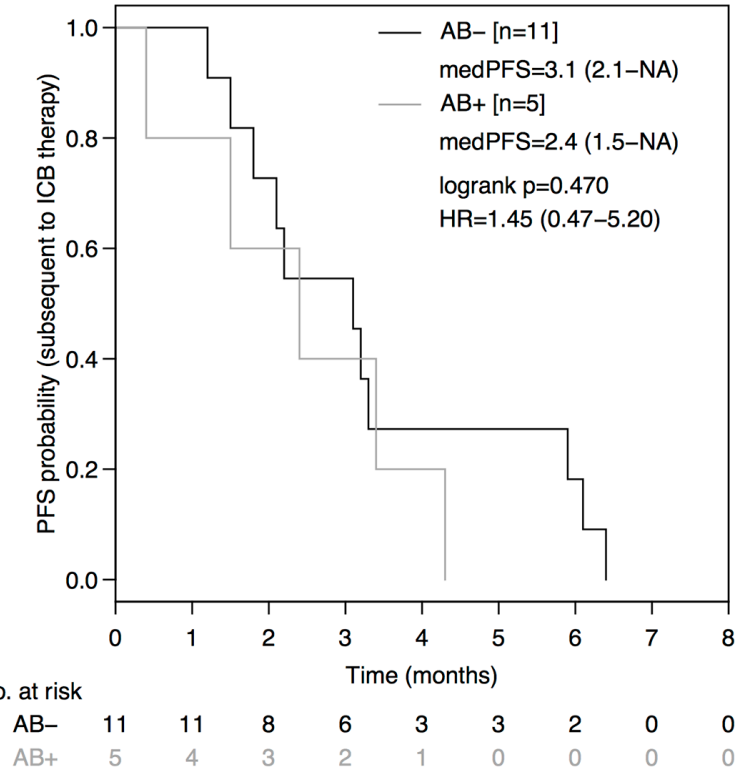

Figure 3: PFS during prior therapy to immune-checkpoint blockade (ICB) and during subsequent therapy based on antibiotic treatment status. Comparison of Kaplan-Meier curves for PFS during prior therapy to ICB (A) and subsequent therapy (B) between $\mathrm{AB}^{-}$and $\mathrm{AB}^{+}$advanced non-squamous NSCLC groups. HR is hazard ratio, $95 \%$ confidence interval in brackets. 
Table 2: Univariate and multivariate analysis for PFS (A) and OS (B) in patients with advanced non-squamous NSCLC treated with immune-checkpoint blockade

\begin{tabular}{|c|c|c|c|c|c|c|c|c|}
\hline \multirow{2}{*}{$\frac{\text { PFS }}{\text { Variable }}$} & \multicolumn{2}{|c|}{ univariate } & \multicolumn{6}{|c|}{ multivariate } \\
\hline & HR & $P$ & levels & $\mathbf{n}$ & events & coef & HR & $\boldsymbol{P}$ \\
\hline $\mathrm{AB}$ & 2.50 & 0.032 & $\begin{array}{l}\text { yes }[n=9] \\
\text { no }[n=16]\end{array}$ & \multirow{8}{*}{25} & \multirow{8}{*}{23} & 1.68 & 5.34 & 0.028 \\
\hline Sex & 1.30 & 0.50 & $\begin{array}{c}\text { female }[\mathrm{N}=13] \\
\text { male }[\mathrm{n}=12]\end{array}$ & & & 0.77 & 2.17 & 0.193 \\
\hline ICB & 1.42 & 0.53 & $\begin{array}{c}\text { pembrolizumab }[\mathrm{n}=5] \\
\text { nivolumab }[\mathrm{n}=20]\end{array}$ & & & 0.27 & 1.31 & 0.691 \\
\hline EGFR mutation & 2.42 & 0.068 & $\begin{array}{l}\text { yes }[n=4] \\
\text { no }[n=21]\end{array}$ & & & 1.03 & 2.79 & 0.131 \\
\hline ALK translocation & 0.95 & 0.95 & $\begin{array}{l}\text { yes }[n=2] \\
\text { no }[n=23]\end{array}$ & & & -0.09 & 0.92 & 0.921 \\
\hline Number of prior therapy lines & 1.04 & 0.92 & $\begin{array}{l}\geq 2[\mathrm{n}=9] \\
\leq 1[\mathrm{n}=16]\end{array}$ & & & 0.57 & 1.76 & 0.370 \\
\hline PD-L1 status & 1.42 & 0.39 & $\begin{array}{l}\text { positive }[n=12] \\
\text { negative }[n=13]\end{array}$ & & & -0.26 & 0.77 & 0.689 \\
\hline IR-AE & 0.69 & 0.35 & $\begin{array}{l}\text { yes }[n=12] \\
\text { no }[n=13]\end{array}$ & & & 0.95 & 2.60 & 0.138 \\
\hline \multicolumn{9}{|l|}{ B } \\
\hline OS & \multicolumn{2}{|c|}{ univariate } & \multicolumn{6}{|c|}{ multivariate } \\
\hline variable & HR & $P$ & levels & $\mathbf{n}$ & events & coef & HR & $P$ \\
\hline $\mathrm{AB}$ & 4.29 & 0.038 & $\begin{array}{l}\text { yes }[n=9] \\
\text { no }[n=16]\end{array}$ & \multirow{8}{*}{25} & \multirow{8}{*}{12} & 2.70 & 14.81 & 0.026 \\
\hline Sex & 1.300 & 0.64 & $\begin{array}{c}\text { female }[\mathrm{N}=13] \\
\text { male }[\mathrm{n}=12]\end{array}$ & & & 2.04 & 7.67 & 0.079 \\
\hline ICB & $<0.1$ & 1.00 & $\begin{array}{c}\text { pembrolizumab }[\mathrm{n}=5] \\
\text { nivolumab }[\mathrm{n}=20]\end{array}$ & & & -20.0 & $<0.1$ & 0.999 \\
\hline EGFR mutation & 2.59 & 0.12 & $\begin{array}{l}\text { yes }[n=4] \\
\text { no }[n=21]\end{array}$ & & & 0.22 & 1.25 & 0.786 \\
\hline ALK translocation & 2.02 & 0.38 & $\begin{array}{l}\text { yes }[n=2] \\
\text { no }[n=23]\end{array}$ & & & 0.90 & 2.46 & 0.374 \\
\hline Number of prior therapy lines & 1.23 & 0.71 & $\begin{array}{l}\geq 2[n=9] \\
\leq 1[n=16]\end{array}$ & & & $-0,62$ & 0.54 & 0.462 \\
\hline PD-L1 status & 1.05 & 0.94 & $\begin{array}{l}\text { positive }[n=12] \\
\text { negative }[n=13]\end{array}$ & & & $-0,59$ & 0.55 & 0.470 \\
\hline IR-AE & 0.65 & 0.43 & $\begin{array}{l}\text { yes }[n=12] \\
\text { no }[n=13]\end{array}$ & & & 1.27 & 3.56 & 0.139 \\
\hline
\end{tabular}

AB: administration of antibiotics within a time frame of one month before to one month after start of immune checkpointblockade; ICB: immune checkpoint blocker; EGFR: epidermal growth factor receptor; ALK: anaplastic lymphoma kinase; PD-L1: programmed death-ligand 1; IR-AE: immune-related adverse events; coeff is the coefficient of the corresponding variable in the Cox regression model, HR is hazard ratio. 
Table 3: Immune-related adverse events in patients with advanced non-squamous NSCLC treated with immunecheckpoint blockade (ICB; $\mathbf{n}=30$ )

\begin{tabular}{|c|c|c|c|c|}
\hline & & $\begin{array}{c}\mathrm{AB}^{+}-\text {group }^{\mathrm{a}} \mathrm{n}=11 \\
(36.7 \%)\end{array}$ & $\begin{array}{c}\mathrm{AB}^{-} \operatorname{\text {group}}^{\mathrm{b}} \mathrm{n}=19 \\
(63.3 \%)\end{array}$ & p-value \\
\hline \multirow{2}{*}{ ICB toxicity ${ }^{*}$ grade $\geq 1$} & Yes & $3(27.3)$ & $11(57.9)$ & \multirow{2}{*}{0.466} \\
\hline & No & $8(72.7)$ & $8(42.1)$ & \\
\hline \multirow{3}{*}{ ICB toxicity" grade } & 1 & $2(18.2)$ & $8(42.1)$ & \multirow{3}{*}{0.142} \\
\hline & 2 & $1(9.1)$ & $3(15.8)$ & \\
\hline & $\geq 3$ & $0(0.0)$ & $0(0.0)$ & \\
\hline \multirow{6}{*}{$\begin{array}{l}\text { ICB organ related } \\
\text { toxicity }^{*}\end{array}$} & Hepatitis & $1(9.1)$ & $2(10.5)$ & \multirow{6}{*}{1.000} \\
\hline & Colitis & $0(0.0)$ & $0(0.0)$ & \\
\hline & Pneumonitis & $0(0.0)$ & $2(10.5)$ & \\
\hline & Thyreoiditis & $2(18.2)$ & $4(21.1)$ & \\
\hline & Skin/itch & $0(0.0)$ & $3(15.8)$ & \\
\hline & Hypophysitis & $0(0.0)$ & $0(0.0)$ & \\
\hline \multirow{3}{*}{$\begin{array}{l}\text { Toxicity related } \\
\text { measures }\end{array}$} & ICB delay & $0(0.0)$ & $3(15.8)$ & \\
\hline & ICB stop & $0(0.0)$ & $1(5.3)$ & \\
\hline & Systemic cortisone use & $0(0.0)$ & $3(15.8)$ & \\
\hline
\end{tabular}

ICB: Immune-checkpoint blockade; toxicity grade based on the Common Terminology Criteria for Adverse Events version 4.03 .

clinical response in NSCLC patients receiving ICB. Fecal microbiota transplantation of responders stools into antibiotics-pretreated mice conferred sensitivity whereas stools from non-responders conveyed resistance to PD-1 blockade. In a translational approach, Type $1 \mathrm{~T}$ helper cell and cytotoxic $\mathrm{T}$ lymphocyte cell reactivity against Akkermansia muciniphila and increased interferon-gamma levels correlated with clinical outcome.

In conclusion, our study demonstrated that a PFS and OS benefit derived from ICB may be attenuated by the administration of antibiotics in temporal proximity to initiation of ICB in advanced non-squamous NSCLC. Our observations are of major importance in a field, where very expensive but effective drugs such as immune-checkpoint inhibitors are still seeking adequate biomarkers and optimized guidelines for their application. Despite the preliminary evidence of these findings, strict indications for the use of antibiotics in temporal proximity to ICB initiation should be recommended. Furthermore, stratification according to antibiotic treatment status may be warranted in future trials investigating ICB.

\section{MATERIALS AND METHODS}

Patients with histologically confirmed advanced non-squamous NSCLC treated with ICB as second- or later line between 2015 and 2017 at our tertiary cancer center in Salzburg, Austria, were included in this retrospective analysis. Patients were defined as evaluable if at least one radiologic reassessment after treatment initiation was available. Radiologic reassessment by PETCT or CT scan was performed every 2 to 3 months, or as clinically indicated. Immune-related adverse events were assessed based on the Common Terminology Criteria for Adverse Events (CTCAE) version 4.03. PFS was calculated from the date of start of ICB until radiologically confirmed progression or death. OS was calculated from the date of start of ICB until date of death or date of last known follow-up. Concomitant (also termed as "in temporal proximity") use of antibiotics was defined as application of antibiotics within a time frame of one month before or one month after initiation of ICB $\left(\mathrm{AB}^{+}-\right.$ group) opposed to antibiotic-naïve patients within the same time frame (AB-group). PD-L1 expression status on tumor cells was assessed by immunohistochemistry utilizing the anti-PD-L1 clone 22C3 from Dako®. PD-L1 positivity was defined as PD-L1 expression in $\geq 1 \%$ of tumor cells. Differences in patient baseline characteristics between the $\mathrm{AB}^{+}$-and $\mathrm{AB}^{-}$-group were tested by two-sided Fisher's exact test. Survival curves were estimated by the Kaplan-Meier method. Log-rank test was used to compare survival distributions between two patient groups. Cox regression models were used for univariate and multivariate analyses of PFS and OS including the parameters antibiotic treatment status, sex, 
immune-checkpoint inhibitor, EGFR mutation status, ALK translocation status, number of prior therapy lines, PDL1 expression status, and immune-related adverse events. Proportional hazard assumptions were tested. All analyses were performed using the statistical software environment $\mathrm{R}$ (version 3.4.1) including package 'survival'.

\section{Abbreviations}

CTL: cytotoxic T-lymphocyte

EGFR: epidermal growth factor receptor

ICB: immune-checkpoint blockade

NSCLC: non-small cell lung cancer

OS: overall survival

PD-L1: programmed death-ligand 1

PFS: progression-free survival

\section{Author contributions}

Florian Huemer, Gabriel Rinnerthaler, and Richard Greil planned, coordinated and conducted the analysis. Florian Huemer, Gabriel Rinnerthaler, Theresa Westphal, Simon Peter Gampenrieder, Lukas Weiss, Hubert Hackl, Georg Hutarew and Richard Greil drafted and prepared the manuscript. Hubert Hackl was responsible for statistical analyses. All authors read, critically discussed and approved the final manuscript.

\section{ACKNOWLEDGMENTS}

Not applicable.

\section{CONFLICTS OF INTEREST}

Florian Huemer: Travel, Accommodations, Expenses: Merck, BMS;

Gabriel Rinnerthaler: Speakers' Bureau: BMS; Theresa Westphal: none; Hubert Hackl: none; MSD;

Georg Hutarew: Consulting or Advisory Role: BMS,

Simon Peter Gampenrieder: Speakers' Bureau: BMS; Travel, Accommodations, Expenses: Merck;

Lukas Weiss: Travel, Accommodations, Expenses: BMS;

Richard Greil: Honoraria: Merck, BMS, MSD; Consulting or Advisory Role: BMS; Research Funding: Merck, BMS, MSD.

\section{FUNDING}

This research did not receive any specific grant from funding agencies in the public, commercial, or not-forprofit sectors.

\section{REFERENCES}

1. Siegel RL, Miller KD, Jemal A. Cancer statistics, 2017. CA Cancer J Clin. 2017; 67:7-30. https://doi.org/10.3322/ caac. 21387.

2. Malvezzi M, Carioli G, Bertuccio P, Rosso T, Boffetta P, Levi F, La Vecchia C, Negri E. European cancer mortality predictions for the year 2016 with focus on leukaemias. Ann Oncol. 2016; 27:725-31. https://doi.org/10.1093/annonc/ mdw022.

3. Brahmer J, Reckamp KL, Baas P, Crino L, Eberhardt WE, Poddubskaya E, Antonia S, Pluzanski A, Vokes EE, Holgado E, Waterhouse D, Ready N, Gainor J, et al. Nivolumab versus docetaxel in advanced squamous-cell non-small-cell lung cancer. N Engl J Med. 2015; 373:12335. https://doi.org/10.1056/NEJMoa1504627.

4. Borghaei H, Paz-Ares L, Horn L, Spigel DR, Steins M, Ready NE, Chow LQ, Vokes EE, Felip E, Holgado E, Barlesi F, Kohlhaufl M, Arrieta O, et al. Nivolumab versus docetaxel in advanced nonsquamous non-small-cell lung cancer. N Engl J Med. 2015; 373:1627-39. https://doi. org/10.1056/NEJMoa1507643.

5. Herbst RS, Baas P, Kim DW, Felip E, Perez-Gracia JL, Han JY, Molina J, Kim JH, Arvis CD, Ahn MJ, Majem M, Fidler MJ, de Castro G Jr, et al. Pembrolizumab versus docetaxel for previously treated, PD-L1-positive, advanced nonsmall-cell lung cancer (KEYNOTE-010): A randomised controlled trial. Lancet. 2016; 387:1540-50. https:/doi. org/10.1016/S0140-6736(15)01281-7.

6. Rittmeyer A, Barlesi F, Waterkamp D, Park K, Ciardiello F, von Pawel J, Gadgeel SM, Hida T, Kowalski DM, Dols MC, Cortinovis DL, Leach J, Polikoff J, et al. Atezolizumab versus docetaxel in patients with previously treated non-small-cell lung cancer (OAK): A phase 3, open-label, multicentre randomised controlled trial. Lancet. 2017; 389:255-65. https://doi.org/10.1016/ S0140-6736(16)32517-X.

7. Vetizou M, Pitt JM, Daillere R, Lepage P, Waldschmitt N, Flament C, Rusakiewicz S, Routy B, Roberti MP, Duong CP, Poirier-Colame V, Roux A, Becharef S, et al. Anticancer immunotherapy by CTLA-4 blockade relies on the gut microbiota. Science. 2015; 350:1079-84. https://doi. org/10.1126/science.aad1329.

8. Sivan A, Corrales L, Hubert N, Williams JB, AquinoMichaels K, Earley ZM, Benyamin FW, Lei YM, Jabri B, Alegre ML, Chang EB, Gajewski TF. Commensal bifidobacterium promotes antitumor immunity and facilitates anti-PD-L1 efficacy. Science. 2015; 350:1084-9. https://doi.org/10.1126/science.aac4255.

9. Boursi B, Mamtani R, Haynes K, Yang YX. Recurrent antibiotic exposure may promote cancer formationAnother step in understanding the role of the human 
microbiota? Eur J Cancer. 2015; 51:2655-64. https://doi. org/10.1016/j.ejca.2015.08.015.

10. Schelenz S, Giles D, Abdallah S. Epidemiology, management and economic impact of febrile neutropenia in oncology patients receiving routine care at a regional UK cancer centre. Ann Oncol. 2012; 23:1889-93. https://doi. org/10.1093/annonc/mdr520.

11. Lee CK, Man J, Lord S, Links M, Gebski V, Mok T, Yang JC. Checkpoint inhibitors in metastatic EGFR-mutated non-small cell lung cancer-a meta-analysis. J Thorac Oncol. 2017; 12:403-7. https://doi.org/10.1016/j.jtho.2016.10.007.

12. Routy B, Le Chatelier E, Derosa L, Duong CPM, Alou MT, Daillere R, Fluckiger A, Messaoudene M, Rauber C, Roberti MP, Fidelle M, Flament C, Poirier-Colame V, et al. Gut microbiome influences efficacy of PD-1-based immunotherapy against epithelial tumors. Science. 2018; 359:91-97. https://doi.org/10.1126/science.aan3706. 